ROCZNIKI NAUK PRAWNYCH

Tom XXX, numer $4-2020$

DOI: https://doi.org/10.18290/rnp20304-4

EMIL KRUK

\title{
DEVELOPMENT OF THE POLISH LEGAL REGULATIONS ON HOMELESS ANIMALS*
}

\author{
INTRODUCTORY REMARKS
}

Despite efforts taken by municipalities and NGOs to prevent homelessness among animals ${ }^{1}$, the number of homeless animals in Poland continues to grow and consequently the number of shelters these animals are kept in. ${ }^{2}$ Problems related to the overpopulation of pets ${ }^{3}$ and the growing scale of animal homelessness

EMIL KRUK PhD - Assistant Professor at the Department of Administrative Law and Administrative Sciences, Institute of Legal Sciences, Faculty of Law and Administration of the Maria Curie-Skłodowska University in Lublin, pl. M. Curie-Skłodowskiej 5, 20-031 Lublin; Poland; e-mail: emil.kruk@umcs.pl; ORCID: https://orcid.org/0000-0002-7954-0303.

* The publication was prepared within the research entitled "The Administrative Law Animal Protection Model" included in the application registered in the Funding Stream Service system administered by National Information Processing Institute after number 2016/23/D/HS5/01820 and accepted for financing within the competition announced by the National Science Centre, Poland - "SONATA 12" on the basis of the decision made by the Director of National Science Centre in Krakow of the 16 of May 2017 (decision no. DEC-2016/23/D/HS5/01820, contract no. UMO-2016/23/D/HS5/01820)

${ }^{1}$ B. KuRZĘPA, E. KuRZĘPA, Wątpliwości dotyczace pojęcia ,zwierzę bezdomne” użytego w ustawie o ochronie zwierzat, "Przegląd Prawa Publicznego" 2016, No. 11, pp. 36-40.

${ }^{2}$ For example, in 2011 there were 150 animal shelters in Poland, while in 2017 the figure was 213. As regards the number of animals under care at shelters, in 2011 all the shelters had: 100265 dogs, 20470 cats and 117 horses, while in 2017 these figures amounted to respectively: 109962 dogs, 32245 cats and 197 horses. It was not until 2018 when a slight decrease in the number of animals held in and received to shelters took place as compared to the previous reference period. There is no more recent data to confirm the downward trend. See annual reports of the Chief Veternary Officer, www.wetgiw.gov.pl/nadzor-weterynaryjny/schroniska-dla-bezdomnych-zwierzat [accessed: 19.10.2020]. See also: Raport o problemie bezdomnych zwierzat, ed. T. Wypych, Warszawa: Fundacja dla zwierząt "Argos" 2016, passim, www.boz.org.pl/raport /2016 [accessed: 19.10.2020].

${ }^{3}$ According to the estimates provided by The European Pet Food Industry (FEDIAF) there were a total of 7750000 dogs and 6600000 cats in Poland in 2019. For comparison: in 2010 these figures amounted to 7311000 dogs and 5550000 cats. See The European Pet Food Industry, FEDIAF, 
are generated by low public awareness of methods of preventing homelessness among animals (this applies in particular to reproduction neutralisation procedures). ${ }^{4}$ To a large extent, this situation stems from numerous omissions and ineptness of the Polish legislature. The best evidence of this is that for decades the problem of homeless animals has been overlooked in the legislation on the humane protection of animals, while other legislation has tried to "solve" it by allowing homeless animals to be caught and killed. In practice, this used to be done during campaigns to fight contagious animal diseases, as part of the broadly understood "protection against homeless animals", or due to the need to protect "free-living" animals (wildlife).

\section{ELIMINATION OF STRAY DOGS "SUSPECTED OF RABIES"}

The first Polish legislation providing for the humane protection of animals, namely the Decree of the President of the Republic of 22 March 1928 on the protection of animals ${ }^{5}$, did not address the issue at all throughout its period of validity, i.e. until 24 October 1997. It also did not provide for a general ban on killing animals, which led to a kind of confirming the solutions adopted under the Decree of the President of the Republic of Poland on combating contagious animal diseases of 22 August $1927 .{ }^{6}$ Specifically, it is an obligation for the competent administrative authorities to order the immediate killing of stray dogs "suspected of rabies". However, animals that came into contact with a an animal with rabies or suspected to be infected, and with dogs and cats, even if it could only be assumed that they had come into contact with such an animal, should be considered suspected of being infected. Only exceptionally, in such cases, could the authorities allow the capture and observation of a dog suspected of being infected (Article 65-67). ${ }^{7}$ Unfortunately, various abuses have

Facts \& Figures 2019, Brussels, pp. 3-4 (orig. pp. 37-38), http://www.fediaf.org/images/FEDIAF_facts _and_figs_2019_cor-35-48.pdf [accessed: 19.10.2020]; The European Pet Food Industry, FEDIAF, Facts \& Figures 2010, Brussels, pp. 3-4, http://www.stray-afp.org/wpcontent/uploads/2012/07/facts _and_figu res_2010.pdf [accessed: 19.10.2020].

${ }^{4}$ Form more on this subject, see: Człowiek wobec bezdomnych zwierzat, ed. J. Szarek, Olsztyn: Uniwersytet Warmińsko-Mazurski 2002, passim; Człowiek wobec bezdomnych zwierzqt. Prawo a rzeczywistość, ed. J. Szarek, Olsztyn: Uniwersytet Warmińsko-Mazurski 2003, passim.

${ }^{5}$ Journal of Laws of 1932, No. 42, item 417.

${ }^{6}$ Journal of Laws no. 77. item 673, as amended.

${ }^{7}$ Under current legislation, the district veterinary officer in a pocket of rabies shall order immediate isolation and observation of animals suspected of being ill or infected. The district 
occurred very often during the implementation of the obligation in question. To prove this, it is worth mentioning an excerpt from the order issued on 31 August 1948 by the Ministry of Agriculture and Agricultural Reform, which reads as follows: "Municipal authorities, required to capture and eliminate stray dogs, in many cases go too far, catching dogs from fenced, closed places, from the hands of owners, etc. The detention and disposal of dogs is also brutal, breaking all humanitarian rules." ${ }^{8}$ For this reason, that order lays down basic rules on the catching of dogs for veterinary reasons, the conditions for keeping them in a rendering facility (knackers' yard) and how they are eliminated. In 1949, Tadeusz Matecki commenting on the situation in his study on the protection of animals in Poland, stated that: "Theoretically, the care of these poor creatures should be taken over by the Society for the Care of Animals, but this is not yet possible, because there is no adequate transport equipment, shelters and funds, etc., to carry out this humanitarian action." $"$

\section{PROTECTION AGAINST HOMELESS ANIMALS}

It was not until the early 1960s that an attempt was undertaken to regulate the issue of homeless animals by means of an internal act aimed at unifying administrative activities in this area. Of course, the fate of such animals was sealed and essentially no different from that of those who were sick or suspected of rabies. According to the guidelines attached to circular letter No. 48 of the Minister of Municipal Economy of 3 October 1961 (ref. no. URT-IV/92/61) on the regulation of the issue of stray dogs and cats in urban areas ${ }^{10}$, unattended animals were to be euthanised, unless picked up by the owners from the shelter, where dogs had to be kept for 14 days and cats for up to 5 days. Dogs could be kept for the next 14 days (up to 28 days in total) at the request and expense of the Society for the Care of Animals, if housing conditions in the shelter allowed it. Within these time limits, the owners of the animals, provided they could prove

veterinary officer may order killing the animals which had contact with a sick animal only where it is necessary. See $\S 2$ (2) items 4 and 5, and $\S 4$ (2) items 1 (a) and (c) of the Ordinance of the Minister of Agriculture and Rural Development of 7 January 2005 on the combating of rabies, Journal of Laws No.13, item 103.

${ }^{8}$ Order of 31 August 1948 issued by the Director f the Veterinary Department of the Ministry of Agriculture and Agricultural Reform of the Republic of Poland (No. Wet. 3-II-4/25), reprinted in: T. MATECKI, Ochrona zwierząt w Polsce, Warszawa: Zarząd Główny Zjednoczenia Towarzystw Opieki nad Zwierzętami R. P. 1949, pp. 228-229.

${ }^{9}$ T. MAtecki, Ochrona zwierzat w Polsce, pp. 96-97.

${ }^{10}$ Official Journal of the Ministry of Municipal Management 1961, item 103. 
the ownership of the animal and upon payment of the fee for the stay of the animal in the shelter, had the right to pick them up, and in the case of dogs, additionally on the condition of fulfilling the obligation to vaccinate the animal against rabies, payment of the tax due and signing the declaration of proper care of the dog. Only purebred dogs, if not picked up by their owners, could be released from the shelter for further breeding to other people than their owners. Only animals which were terminally or contagiously ill were to be immediately euthanised based on the diagnosis of a veterinarian. Animals suffering from non-contagious diseases and with prospects of recovery could be treated within 14 days of staying in the shelter at the request and expense of the Society for the Care of Animals. Animals brought to shelters was to be euthanised free of charge and in a humane manner by a veterinarian or under his supervision. However, after paying the related costs, the shelter staff, at the request of the persons concerned, was also required to euthanise animals at the owner's premises It is also significant that the performance of direct tasks covered by the guidelines and not delegated to the branches of the Society for the Care of Animals was the responsibility of municipal sanitation departments (enterprises), while the financial resources for this activity were to be allocated under part 7 of chapter 12 ("Cleansing") of national council budgets. The assumption was that stray animals were supposed to be brought to shelters by local people ${ }^{11}$, who should have also been informed as part of "propaganda campaigns" about the possibility of bringing "animals unfit for breeding, especially blind litters of dogs and cats" to be euthanised. The shelters could be run by municipal sanitation departments (enterprises) and by branches of the Society for the Care of Animals. They were subject to permanent supervision by a veterinary officer. Shelter staff members were required to have a humane attitude towards animals and be trained in the proper handling of animals. The premises designated for animal shelters were to be adapted to their needs, and in particular, they were supposed to meet the sanitary and hygienic requirements, have heating, water supply and connection to the sewage system (or a septic tank), devices for preparing (cooking) the food, compartments with paddocks for dogs, cages for cats, separate quarantine compartments, a room for liquidation of animals and a small storage unit. Animals placed in shelters were to be fed regularly. The humanitarian activity aimed at solving the problem of stray animals was to be guaranteed also by introducing a kind of requirement of cooperation and mutual control by competent administrative authorities and the Society for the Care of Animals. As far

\footnotetext{
${ }^{11}$ Apart from the participation by general public, also designated employees of shelters had the responsibility to bring animals to shelters.
} 
as the above-mentioned cooperation is concerned, municipal sanitation departments (enterprises) were obliged to use the experience and assistance of the Society for the Protection of Animals to the widest possible extent. In turn, the relevant branches of the Society for the Protection of Animals were supposed to take part in the drafting of detailed regulations for the operation of shelters and to participate in shelter staff training in the proper handling of animals. On the other hand, the branches of the Society for the Protection of Animals, which were commissioned to perform the tasks covered by the guidelines in this area, were subject to the supervision and control of the presidium of the municipal national council (through the municipal and housing management department), while representatives of the Society for the Protection of Animals were authorized to carry out "social inspections" of shelters run by municipal sanitation departments (enterprises) with regard to humane handling of animals.

\section{PROVIDING CARE TO HOMELESS ANIMALS}

The real purpose of the solutions described above, which certainly was not to protect stray dogs and cats, was in a way confirmed by the Act of 13 September 1996 on maintaining cleanliness and order in communes ${ }^{12}$ (hereinafter : AMCOC), which in Article 3 (2)(5) (in the wording applicable until December 31, 2011) imposed on communes the obligation to ensure cleanliness and order in their area of responsibility and to create the conditions necessary for their maintenance, including the "organisation of protection against homeless animals on the rules as set out in separate regulations." However, this issue was regulated only in the Act of 21 August 1997 on the protection of animals ${ }^{13}$ (hereinafter APA), which on 24 October 1997 replaced the above-mentioned Decree of the President of the Republic of 22 March 1928 on the protection of animals. According to the original wording of Article 11 paragraphs 1, 3 and 4 APA, communes were required to provide care for $^{14}$ and to catch homeless animals, which, like the "the deciding on the further proceeding with them", could only take place pursuant to a resolution of the relevant municipal council, adopted upon consultation with the state veterinarian and after consulting the authorised representative of the Society for the Care of Animals in Poland or other non-governmental

\footnotetext{
${ }^{12}$ Journal of Laws of 2018, item 1454, as amended.

${ }^{13}$ Journal of Laws of 2019, item 122.

${ }^{14}$ According to Article 4 (16) APA, the term "homeless animal" should be understood as a pet or working animal which escaped, went astray or was abandoned by a man and it is impossible to identify its owner or other person under whose permanent custody was before.
} 
organization with a similar statutory purpose. At the same time, these organizations were authorized to care for homeless animals and to run animal shelters for this purpose (in consultation with the competent local government bodies). In turn, according to the authorisation contained in Article 11 (2) APA, the Minister of the Interior and Administration issued on 26 August 1998 Ordinance on the principles and conditions for catching homeless animals. ${ }^{15}$ According to the ordinance, catching homeless animals could be of a regular or periodic nature, depending on the content of the resolution adopted in this matter by the municipal council. At the same time, the commune's body was obliged to publicly disclose, in a manner habitually used in a given area, at least 21 days before the planned date of commencement of catching homeless animals: 1) date of the catching; 2) the boundaries of the area where they will be caught; 3 ) the address of the shelter with which the placement of animals after catching has been agreed; 4) the entity which carries out the catching. According to this ordinance, measures to catch homeless animals, including in particular dogs and cats, involved catching by an entity with which the municipal authority had concluded a contract to carry out such operations and to transport and place the animals in a shelter. The contract for catching homeless animals could be entered into by the municipal authority with an entity operating a shelter or with a business operator. Such an agreement should include in particular: 1) a list of the facilities and means by which the animals will be caught (they must not endanger or cause suffering to their lives and health); 2) a specification of means for the transport of animals (they should meet the conditions referred to in the APA); 3) ensuring, where necessary, medical and veterinary assistance; 4) an indication of the place where the animals caught are to be kept before being transported to the shelter (as a general rule, once captured, homeless animals should be transported immediately to the shelter).

As you can see, the provisions described above have, for quite a long time, remained inconsistent with respect to the subject of protection ("protection against homeless animals" / "providing care to homeless animals"). Moreover, they were formulated, including secondary legislation, at a fairly high level of generality and did not specify the requirement to provide homeless animals with a place in shelters and did not address such important issues as, for example, the prevention of animal homelessness, the manner of further proceeding with the animals or the veterinary conditions to be met by the shelter. Certain modifications in this respect were introduced by the Act of 16 September 2011

\footnotetext{
${ }^{15}$ Journal of Laws No. 116, item 753.
} 
amending the Act on the protection of animals and the Act on maintaining cleanliness and order in communes ${ }^{16}$, effective since 1 January 2012. The amendment changed the wording of Article 3(2) item14 $\mathrm{AMCOC}^{17}$ by introducing, instead of the current obligation of "protection against homeless animals", the order of the "prevention of animal homelessness" imposed on communes. ${ }^{18}$ As regards the APA, the modification covered e.g. the provision of Article 11(3) where a ban on catching homeless animals without providing them with a place in an animal shelter was introduced. The only exception is where an animal poses a serious risk to humans or other animals and a custodial sentence or fine is provided for breaching the prohibition (Article 37(1) APA). Furthermore, the legislature decided to add to Article 4 APA, beside other statutory definitions, the definition of "animal shelter", according to which it is to be understood as a place intended for the care of animals that meets the conditions set out in the Act of 11 March 2004 on the protection of animal health and combating infectious animal diseases. ${ }^{19}$ According to the explanatory memorandum to the draft law which introduced the amendment in question, that solution was intended to provide animals with more complete protection. In the opinion of the proponents of the draft act: "'It is extremely important to make this term more precise, since the lack of clarification of the terms of shelter and care for animals has given rise to the establishment of a huge number of various places where animals are kept, which due to the lack of this definition are beyond any supervision and control. Under the legislation currently in force, not all the animals caught in municipalities go to legalised shelters, many of them simply disappear or are handed over to different places, sometimes called euphemistically animal hotels or hostels. The complete lack of control by the municipalities and, in addition, the lack of control by the Veterinary Inspectorate, sanctioned by internal regulations, leads to the mass extermination of animals. The introduction of a precise definition of animal shelter will, first of all, allow any such facility to be taken into account in the supervision and audit. This is also part

\footnotetext{
${ }^{16}$ Journal of Laws No. 230, item 1373.

${ }^{17}$ The original wording of Article 3 (2) AMCOC was also amended by Article1 (5)(a) of the Act of 1 July 2011 amending the Act on maintaining cleanliness and order in communes and certain other acts, (Journal of Laws No. 152, item 897, as amended), which became effective on 1 January 2012.

${ }^{18}$ One should agree with D. Cyman that "animal homelessness prevention comprises also the obligation of protection against homeless animals." See D. CYMAN, Obowiazki gmin w zakresie opieki nad bezdomnymi zwierzętami, [in:] Finanse publiczne jednostek samorzadu terytorialnego. Źródta finansowania samorządu terytorialnego we wspótczesnych regulacjach prawnych, eds. J. Gliniecka, E. Juchniewicz, T. Sowiński, Warszawa: CeDeWu Sp. z o.o. 2014, p. 293 and the case-law of the European Court of Human Rights referred to therein.

${ }^{19}$ Journal of Laws of 2018, item 1967.
} 
of the fight against illegal breeding farms, which are often run on a large scale." ${ }^{20}$ For the sake of clarity, it is worth adding at this point that the fact that it was only in 2012 that the definition of "animal shelter" appeared in Polish legislation does not mean that, until then, the functioning of such entities was outside any legal regulation. The requirements to be met by animal shelters are set out in the Ordnance of the Minister of Agriculture and Food Management of 21 January 1999 on detailed veterinary conditions required for organizing fairs, roundups and exhibitions, and running animal shelters ${ }^{21}$, then in the Ordnance of the Minister of Agriculture and Rural Development of 5 November 2002 on the detailed veterinary conditions required for running animal shelters ${ }^{22}$ and currently in the Ordinance of the Minister of Agriculture and Rural Development of 23 June 2004 on the detailed veterinary requirements for running animal shelters. ${ }^{23}$ The applicable regulations specify requirements for: shelter location; preparing the area where the shelter is to be located; rooms to be ringfenced in the shelter and the materials used to finish them; technical equipment necessary for the disposal or temporary storage of animal corpses; equipping the compartments; access to paddocks; veterinary care and compulsory vaccinations; training of people employed for handling the animals; documentation kept (list of animals in the shelter, veterinary inspection book).

To conclude this part of the considerations, it should be stressed that the entire burden of preventing and providing care for homeless animals lies with the municipalities (Article 11(1) APA). ${ }^{24}$ To guarantee proper performance of these obligations, the legislature, in Article 11a APA, has required the municipal councils to adopt, by way of a resolution, by 31 March each year, the programmes

\footnotetext{
${ }^{20}$ See explanatory note to member's bill amending the Act on maintaining cleanliness and order in communes and certain other acts (Sejm Papers no. 4257), Warszawa, 12 May 2011, p. 6, http://orka.sejm.gov.pl/Druki6ka.nsf/0/08D26EF6B5358A78C125789D00381AF6/\$file/4257.pdf [accessed: 19.10.2020].

${ }^{21}$ Journal of Laws No. 9, item 84.

${ }^{22}$ Journal of Laws No. 192, item 1611.

${ }^{23}$ Journal of Laws No. 158, item 1657.

${ }^{24}$ M. Szalewska, Counteracting Animal Homelessness and Providing Care for Stray Animals as a Task of a Commune, "Polish Yearbook of Environmental Law" 6 (2016), pp. 91-107, https://apcz.umk.pl/czasopisma/index.php/PYEL/article/view/PYEL.2016.006/10976 [accessed: 19.10.2020]; A. GoleniA, M. MAREK, Zadania wtasne gminy w zakresie praw zwierzat, [in:] Urzędnik jako strażnik realizacji ustawowych obowiąków wobec zwierząt, eds. T. Pietrzykowski, A. Bielska-Brodziak, K. Gil, M. Suska, Katowice: Wydawnictwo Uniwersytetu Śląskiego 2016, pp. 13-29.
} 
of care for homeless animals and prevention of animal homelessness. ${ }^{25}$ According to the current wording of Article 11a (2) APA, such programme includes in particular: 1) providing homeless animals with a place in an animal shelter; 2) care for free-living cats, including their feeding; 3) catching homeless animals; 4) obligatory sterilization or castration of animals in animal shelters; 5) seeking owners for homeless animals; 6) euthanasia of blind litter; 7) specification of the farm to provide a space for farm animals; 8) providing round-the-clock veterinary care in cases of traffic incidents involving animals. Moreover, pursuant to Article 11a(5) APA, the programme must specify the amount of funds allocated for its implementation and the manner of spending those funds (the costs of implementing the programme is to be borne by the municipality). The list presented above includes obligatory elements of the programmes. Thus, when adopting a resolution on the programme of care of homeless animals and prevention of homelessness of animals, the legislative body of the municipality may not ignore any of the elements listed in Article 11a(2) and (5) APA. The functioning of municipal programmes for care of homeless animals and prevention of animal homelessness entails many problems, but these are issues which go far beyond the framework of this study.

\section{CONTROL OF FERAL DOGS AND CATS IN HUNTING DISTRICT}

In its original version, Article 23(1) APA provided for the possibility of control of animals which pose a threat to human life, health or the economy. ${ }^{26}$ However, in accordance with the authorisation contained in paragraph 2 of that article, the ministers indicated therein were entitled to determine, by means of a regulation, the conditions, time and means of this control. This provision was deleted as of 28 September 2002 by Article 1(18) of the Act of

\footnotetext{
${ }^{25}$ See the remarks by $€$. Smaga on the humanitarian value of activities that may be covered by the municipal animal homelessness prevention programme, such as "seeking new owners", "sterilization and castration" and "euthanasia of blind litter." Ł. SMAGA, Ochrona humanitarna zwierzat, Białystok: Agencja Wydawniczo-Edytorska EkoPress 2010, p. 241 et seq.

${ }^{26}$ Earlier, Article 23 of the Act of 17 June 1959 on breeding and the protection of wild game and the hunting law (Journal of Laws of 1973, No. 33, item 197, as amended) provided for that: People authorized for hunting (Article 29 (2)), officers of the Citizens' Militia, hunting guards, employees of state forests in forest areas, and authorized employees of state farming enterprises in agricultural areas are obliged to shoot stray dogs and cats in the hunting district". This regulation was not "taken over" by the current Act of 13 October 1995, Hunting Law, Journal of Laws of 2018, item 2033, as amended.
} 
6 June 2002 amending the Act on the protection of animals ${ }^{27}$, which was kind of replaced by Article 33a, according to which, where animals pose an extraordinary threat to human life, health or the economy, including the hunting industry, it is allowed to take measures to reduce the population of such animals. However, and this is particularly important in view of the considerations at this point, under Article 33a(3) APA, feral dogs and cats, unaccompanied and unattended by human beings in hunting districts more than $200 \mathrm{~m}$ from residential areas and posing a threat to wildlife, including wild game, could be controlled by tenants or administrators of hunting districts. Apart from all the interpretative doubts raised by this provision, and in particular the discussion on the condition of "going feral." ${ }^{28}$ It should be noted that the solution it provided for was, above all, contrary to the fundamental goal of the Act, which is the protection of animals and not the interests of the hunting industry. A similar view was expressed by the Polish Ombudsman, who, in a speech addressed to the Marshal (Speaker) of the Sejm, stated that the provision of Article 33a APA is "a breakthrough in the philosophy of the Animal Protection Act." ${ }^{, 29}$ The challenged regulation was amended by Article 1(11) of the Act of 16 September 2011 amending the Act on the protection of animals and the Act on maintaining cleanliness and order in communes. ${ }^{30}$ According to the current wording of Article 33a(3) APA, the tenant or administrator of a hunting district may take action to prevent dogs from roaming around in the district by: 1) instructing the owner of the dog about the obligation to attend the animal; 2) catching the dog and delivering it to the owner, and if the owner cannot be identified, delivering the dog to an animal shelter (the catching and delivering the dog is

${ }^{27}$ Journal of Laws No. 135, item 1141.

${ }^{28}$ A. ŻUKOwSKI, Zwalczanie psów i kotów w obwodach łowieckich, "Prokuratura i Prawo" 2007, No. 12, p. 129 et seq.; W. RADECKI, Oceny prawne zwalczania zdziczałych psów i kotów w obwodzie towickim, [in:] Księga pamiatkowa profesora Ryszarda Paczuskiego, ed. Z. Bukowski, Torun: Towarzystwo Naukowe Organizacji i Kierownictwa. Stowarzyszenie Wyższej Użyteczności "Dom Organizatora" 2004, p. 297 et seq.; N. Dobrowolska, Status prawny psa w Polsce. Poradnik praktyka psiarza, Brzezia Łąka: Wydawnictwo Poligraf 2018, pp. 137-141; M. GoETTEL, Sytuacja zwierzecia w prawie cywilnym, Warszawa: Wolters Kluwer Polska 2013, pp. 65-67. See also the substantiation of the judgement of the Constitutional Tribunal of 10 January 2012, case ref. no. K 8/11, OTK ZU 2012, vol. 1, item 7.

${ }^{29}$ Submission of the Ombudsman to the Marshal of the Sejm of the Republic of Poland of 18 December 2003 regarding statutory norms allowing shooting animals on private (agricultural) land without the consent of their owners, case ref. no. RPO/420948/02/X/1003.7 RZ, https://sprawygeneralne.brpo.gov.pl/index.php?sprawa=3570 [accessed: 19.10.2020].

${ }^{30}$ Journal of Laws No. 230, item 1373. 
done at the owner's expense).$^{31}$ However, this does not mean, to put it bluntly, that currently dogs and cats may not be shot under any circumstances in hunting districts. It should be kept in mind that pursuant to Article 6(1) item 5 APA, it is prohibited to kill animals, with the exception of the eradication of those directly posing risk to people or other animals, if no other way of removing the threat is possible, which can only be done in a humane manner by inflicting a minimum of physical and mental suffering.

\section{FINAL REMARKS}

As confirmed by the research, Polish municipalities have quite recently been obliged to provide care for homeless animals. Unfortunately, the legal regulations in this area are characterized by numerous shortcomings, which make them ineffective. The adopted normative solutions are more focused on remedying the effects than on preventing the causes of the problem of homelessness of animals. This concerns in particular the lack of a statutory requirement of marking all cats and dogs and a central register in which they could be registered. The provisions in question do not specify the obligations of municipalities in the field of monitoring the fate of homeless animals caught and placed in shelters or looking for new owners for them. Moreover, the obligation to provide care to homeless animals was imposed on local government entities without providing financial resources for its fulfilment. In such a situation, municipalities do not always duly fulfil the obligation, and the related problems are additionally make more serious by the lack of proper supervision. The problem of animal homelessness requires systemic solutions. Nonetheless, the fact that under the legislation currently in force caught homeless animals are not subject to killing should not especially comfort anyone. It is true since an alternative to such a solution is usually keeping animals in shelters, which is hardly a humanitarian solution, especially that living conditions in shelters often differ from the standard defined by law.

\footnotetext{
${ }^{31}$ For more on the dysfunctionality of Article 33a (3) APA, see: H. RASZ, M. GwIAZDOwICZ, Opinia $w$ sprawie poselskiego projektu ustawy o zmianie ustawy o ochronie zwierzat oraz ustawy o utrzymaniu czystości i porzadku w gminach (druk nr 4257), Warszawa, dnia 16 lipca 2011 r., pp. 6-7, http://orka.sejm.gov.pl/rexdomk6.nsf/Opdodr?OpenPage\&nr=4257 [accessed: 19.10.2020]; W. RADECKI, Ustawy o ochronie zwierzqt. Komentarz, Warszawa: Difin 2015, p. 181 et seq.
} 


\section{BIBLIOGRAPHY}

SOURCES OF LAW

Ustawa z dnia 17 czerwca 1959 r. o hodowli, ochronie zwierząt łownych i prawie łowieckim, Dz.U. 1973, Nr 33, poz. 197 z późn. zm.

Ustawa z dnia 13 października 1995 r. - Prawo łowieckie, Dz.U. 2018, poz. 2033 z późn. zm.

Ustawa z dnia 13 września 1996 r. o utrzymaniu czystości i porządku w gminach, Dz.U. 2018, poz. 1454 z późn. zm.

Ustawa z dnia 21 sierpnia 1997 r. o ochronie zwierząt, Dz.U. 2019, poz. 122.

Ustawa z dnia 6 czerwca 2002 r. o zmianie ustawy o ochronie zwierząt, Dz.U. Nr 135, poz. 1141.

Ustawa z dnia 11 marca 2004 r. o ochronie zdrowia zwierząt oraz zwalczaniu chorób zakaźnych zwierząt, Dz.U. 2018, poz. 1967.

Ustawa z dnia 1 lipca 2011 r. o zmianie ustawy o utrzymaniu czystości i porządku w gminach oraz niektórych innych ustaw, Dz.U. Nr 152, poz. 897 z późn. zm.

Ustawa z dnia 16 września 2011 r. o zmianie ustawy o ochronie zwierząt oraz ustawy o utrzymaniu czystości i porządku w gminach, Dz.U. Nr 230, poz. 1373.

Rozporządzenia Prezydenta Rzeczypospolitej z dnia 22 sierpnia 1927 r. o zwalczaniu zaraźliwych chorób zwierzęcych, Dz.U. Nr 77, poz. 673 z późn. zm.

Rozporządzenie Prezydenta Rzeczypospolitej z dnia 22 marca 1928 r. o ochronie zwierząt, Dz.U. z 1932 r., Nr 42, poz. 417.

Rozporządzenie Ministra Spraw Wewnętrznych i Administracji z dnia 26 sierpnia 1998 r. w sprawie zasad i warunków wyłapywania bezdomnych zwierząt, Dz.U. Nr 116, poz. 753.

Rozporządzenie Ministra Rolnictwa i Gospodarki Żywnościowej z dnia 21 stycznia 1999 r. w sprawie szczegółowych warunków weterynaryjnych wymaganych przy organizowaniu lub urządzaniu targów, spędów i wystaw zwierząt oraz prowadzeniu schronisk dla zwierząt, Dz.U. Nr 9, poz. 84.

Rozporządzenie Ministra Rolnictwa i Rozwoju Wsi z dnia 5 listopada 2002 r. w sprawie szczegółowych warunków weterynaryjnych wymaganych przy prowadzeniu schronisk dla zwierząt, Dz.U. Nr 192, poz. 1611.

Rozporządzenie Ministra Rolnictwa i Rozwoju Wsi z dnia 23 czerwca 2004 r. w sprawie szczegółowych wymagań weterynaryjnych dla prowadzenia schronisk dla zwierząt, Dz.U. Nr 158, poz. 1657.

Rozporządzenia Ministra Rolnictwa i Rozwoju Wsi z dnia 7 stycznia 2005 r. w sprawie zwalczania wścieklizny, Dz.U. Nr 13, poz. 103.

Zarządzenie Dyrektora Departamentu Weterynarii Ministerstwa Rolnictwa i Reform Rolnych RP z dnia 31 sierpnia 1948 r., Nr. Wet. 3-II-4/25.

Wytyczne w sprawie uregulowania zagadnienia bezpańskich psów i kotów na terenie miast, stanowiące załącznik do pisma okólnego nr 48 Ministra Gospodarki Komunalnej z dnia 3 października 1961 r. (L. dz. URT-IV/92/61), Dz. Urz. M.G.K. 1961, poz. 103.

\section{CASE LAW}

Postanowienie TK z dnia 10 stycznia 2012 r., sygn. akt K 8/11, OTK ZU 2012, z. 1A, poz. 7. 


\section{LiTERATURE}

Cyman Damian: Obowiązki gmin w zakresie opieki nad bezdomnymi zwierzętami, [in:] Finanse publiczne jednostek samorządu terytorialnego. Źródła finansowania samorządu terytorialnego we współczesnych regulacjach prawnych, eds. J. Gliniecka, E. Juchniewicz, T. Sowiński, Warszawa: CeDeWu Sp. z o.o. 2014, pp. 291-301.

Człowiek wobec bezdomnych zwierząt, ed. J. Szarek, Olsztyn: Uniwersytet Warmińsko-Mazurski 2002.

Człowiek wobec bezdomnych zwierząt. Prawo a rzeczywistość, ed. J. Szarek, Olsztyn: Uniwersytet Warmińsko-Mazurski 2003.

DoBRowolska Natalia: Status prawny psa w Polsce. Poradnik praktyka psiarza, Brzezia Łąka: Wydawnictwo Poligraf 2018.

GoeTtel Mieczysław: Sytuacja zwierzęcia w prawie cywilnym, Warszawa: Wolters Kluwer Polska 2013.

Golenia Anna, MAREK Malwina: Zadania własne gminy w zakresie praw zwierząt, [in:] Urzędnik jako strażnik realizacji ustawowych obowiązków wobec zwierząt, eds. T. Pietrzykowski, A. Bielska-Brodziak, K. Gil, M. Suska, Katowice: Wydawnictwo Uniwersytetu Śląskiego 2016, pp. 13-29.

KURZĘPA Bolesław, KURZĘPA Elżbieta: Wątpliwości dotyczące pojęcia „,zwierzę bezdomne” użytego w ustawie o ochronie zwierząt, „Przegląd Prawa Publicznego” 2016, No. 11, pp. 36-40.

Matecki Tadeusz: Ochrona zwierząt w Polsce, Warszawa: Zarząd Główny Zjednoczenia Towarzystw Opieki nad Zwierzętami R. P. 1949.

RADECKI Wojciech: Oceny prawne zwalczania zdziczałych psów i kotów w obwodzie łowickim, [in:] Księga pamiątkowa profesora Ryszarda Paczuskiego, ed. Z. Bukowski, Toruń: Towarzystwo Naukowe Organizacji i Kierownictwa. Stowarzyszenie Wyższej Użyteczności “Dom Organizatora" 2004, pp. 287-300.

RADECKI Wojciech: Ustawy o ochronie zwierząt. Komentarz, Warszawa: Difin 2015.

SMAGA Łukasz: Ochrona humanitarna zwierząt, Białystok: Agencja Wydawniczo-Edytorska EkoPress 2010.

SzAlewsKa Małgorzata: Counteracting Animal Homelessness and Providing Care for Stray Animals as a Task of a Commune, "Polish Yearbook of Environmental Law" 6 (2016), pp. 91-107, https://apcz.umk.pl/czasopisma/index.php/PYEL/article/view/PYEL.2016.006/10976 [accessed: 19.10 .2020$]$.

ŻuKowski Arkadiusz: Zwalczanie psów i kotów w obwodach łowieckich, "Prokuratura i Prawo" 2007, No. 12, pp. 123-135.

OTHER

Raport o problemie bezdomnych zwierząt, ed. T. Wypych, Warszawa: Fundacja dla "Zwierząt Argos" 2016, www.boz.org.pl/raport/2016 [accessed: 19.10.2020].

Raporty roczne Głównego Lekarza Weterynarii z wizytacji schronisk dla zwierząt za lata 2012-2018, www.wetgiw.gov.pl/nadzor-weterynaryjny/schroniska-dla-bezdomnych-zwierzat [accessed: 19.10.2020].

RASZ Hanna, GwIAZDOwiCZ Mirosław: Opinia w sprawie poselskiego projektu ustawy o zmianie ustawy o ochronie zwierząt oraz ustawy o utrzymaniu czystości i porządku w gminach (druk $\mathrm{nr}$ 4257), 
Warszawa, dnia 16 lipca 2011 r., http://orka.sejm.gov.pl/rexdomk6.nsf/Opdodr?OpenPage\& $\mathrm{nr}=4257$ [accessed: 19.10.2020].

The European Pet Food Industry, FEDIAF, Facts \& Figures 2010, Brussels, 19.10.2020].

The European Pet Food Industry, FEDIAF, Facts \& Figures 2019, Brussels, http://www.fediaf.org/images /FEDIAF_facts_and_figs_2019_cor-35-48.pdf [accessed: 19.10.2020].

Uzasadnienie poselskiego projektu ustawy o zmianie ustawy o ochronie zwierząt oraz ustawy o utrzymaniu czystości i porządku w gminach (druk sejmowy nr 4257), Warszawa, 12 maja $2011 \mathrm{r}$., http://orka.sejm.gov.p1/Druki6ka.nsf/0/08D26EF6B5358A78C125789D00381AF6/\$file/4257.pdf [accessed: 19.10.2020].

Wystąpienie Rzecznika Praw Obywatelskich do Marszałka Sejmu RP z dnia 18 grudnia 2003 r. w sprawie norm ustawowych umożliwiających strzelanie do zwierząt na terenach prywatnych (rolniczych) bez zgody ich właścicieli, sygn. RPO/420948/02/X/1003.7 RZ, https://sprawygeneralne.brpo.gov.pl/index.php?sprawa=3570 [accessed: 19.10.2020].

\section{DEVELOPMENT OF THE POLISH LEGAL REGULATIONS ON HOMELESS ANIMALS}

\section{Summary}

The main aim of the article is to discuss the development of Polish legal regulations on homeless animals. The research demonstrated that the problem of the protection of homeless animals had been marginalized by the Polish legislature for decades. This contributed significantly to the overpopulation of domestic animals and a significant increase in the number of homeless animals. The regulations currently in force fail to solve this problem as they focus more on remedying the effects of homelessness of animals than on preventing this problem.

Key words: Poland; law; animal protection; humanitarian protection; stray animal; care; animal shelter; rabies; hunting district

\section{ROZWÓJ POLSKICH REGULACJI PRAWNYCH DOTYCZĄCYCH ZWIERZĄT BEZDOMNYCH}

\section{Streszczenie}

Zasadniczym celem artykułu jest omówienie rozwoju polskich uregulowań prawnych dotyczących zwierząt bezdomnych. Przeprowadzone badanie wykazało, że problem ochrony zwierząt bezdomnych przez całe dziesięciolecia był marginalizowany przez polskiego ustawodawcę. Przyczyniło się to w istotnym stopniu do powstania nadpopulacji zwierząt domowych i znacznego wzrostu liczby zwierząt bezdomnych. Obowiązujące aktualnie unormowania nie rozwiązują tego problemu, ponieważ bardziej koncentrują się na usuwaniu skutków bezdomności wśród zwierząt, niż na zapobieganiu temu problemowi.

Słowa kluczowe: Polska; prawo; ochrona zwierząt; ochrona humanitarna; zwierzę bezpańskie; opieka; schronisko dla zwierząt; wścieklizna; obwód łowiecki 